\title{
The Teacher'S Role in the Formation of the Attitude and Performance of Students in the Subject of Geography
}

\author{
Likouri Anna-Aikaterini $^{1, *} \&$ Klonari Aikaterini ${ }^{1}$ \\ ${ }^{1}$ Dept. of Geography, University of the Aegean, University Hill, Mytilene, 81100, Lesvos, \\ Greece \\ *Corresponding author: Dept. of Geography, University of the Aegean, University Hill, \\ Mytilene, 81100, Lesvos, Greece. Tel: 30-697-764-2939. E-mail: katial25@yahoo.gr
}

Received: December 10, 2017 Accepted: December 17, 2017 Published: December 23, 2017

doi:10.5296/ije.v9i4.12317 URL: https://doi.org/10.5296/ije.v9i4.12317

\begin{abstract}
The purpose of this study was to investigate the attitude of teachers and students towards the subject of geography, and whether it affects the students' performance. The sample comprised 600 6th-grade primary school students from various areas of Greece, and their 33 teachers. The following findings were made: a) the largest part of the teachers and students shows a medium or poor attitude towards the subject of geography; b) teachers' reeducation did not seem to improve either the attitude of teachers or the attitude and performance of their students; c) prior working experience of teachers did not appear to affect attitude, but it does affect performance of their students in geography; d) the teaching method (traditional or with the use of technologies) did not appear to differentiate the students' attitude towards geography.
\end{abstract}

Keywords: geography education, teachers, attitude, school performance, Greece 


\section{Introduction}

The teacher's role has always been particularly important for the development of students' achievement and performance (Soric, 2011; Ulug, Ozden, \& Eryilmaz, 2011). However, the role of teachers has fundamentally changed. International trends in education show a shift from the traditional "teacher centred" approach to a "student centred" approach, with the implementation, in several courses, of new technologies. Students aren't consumers of facts any more, but they are active creators of knowledge. Therefore, teachers ought to change the traditional teaching methods, and apply more innovative, participatory, and active practices in the classroom (UNESCO, 2004; Luciano, 2014). They grasp that their most important role is to get to know each student as an individual in order to comprehend his or her unique needs, learning style, social and cultural background, interests, and abilities. Teachers' current role is helping students "learn how to learn", by developing their abilities to think critically, solve problems, make informed judgments, and create their knowledge. In modern classrooms, teachers are no longer lecturers, they can be thought of as facilitators in the learning process, supporters, advisors and their main task is to set goals and organise the learning process accordingly (Flouris, 2000; Zhuang, 2010).

It is well known that the positive and negative behaviors exhibited by teachers determine to a great extent their effectiveness in the classroom and, ultimately, the impact they have on student achievement (Matsagouras, 2000; Stronge, 2007).

Moreover, Ames \& Archer (1988) showed that students' perceptions of classroom climate were related to specific motivational variables that have significant implications for the development of self-regulated learning as well as a long-term involvement and interest in learning. I.e. students who perceived an emphasis on learning goals in the classroom reported using more effective strategies, preferred challenging tasks, had a more positive attitude toward the class, and had a stronger belief that success follows from one's effort. Students who perceived performance goals as salient tended to focus on their ability, evaluating their ability negatively and attributing failure to lack of ability (Ames \& Archer, 1988, p.1).

There are some reasons for students' poor performance that are specific or related to school. Several studies focus on teaching models or approaches that have effects on curricula designing and educational environments, from the perspective of encouraging students' learning (Burden \& Byrd, 1994; Coffin, 1994; Joyce \& Weil, 1996; UNESCO, 2004; Moler, 2008; Luciano, 2014). Others examine the teachers' skills in applying creative and personalized teaching methods through art, in which case effective teachers create enthusiasm, and make the learning objectives clear (Harris, 1998). But there are many researches that reported that teachers matter more to student achievement than any other aspect of schooling (Rosenshine, 1983; Brophy \& Good, 1986; Rose, 1989; Chalkia, 1999; Klonari \& Koutsopoulos, 2005; Soric, 2011; Ulug, Ozden, Eryilmaz 2011; Schneider, Coutts, and Gruman, 2012). They play a crucial role in educational attainment because the teacher is ultimately responsible for translating educational policy into action and principles based on practice during interaction with the students (Adeyemi, 2010; Alderman, 2008; Heck, 2009; Prassas, 2013). Wright, Horn and Sanders (1997) concluded that the most important factor 
influencing student learning is the teacher.

More specifically, researchers report that the deficiency of students in geographic knowledge, as well as their negative attitudes towards geography related to teachers' negative behaviour, traditional way of teaching and insufficient content knowledge of the subject (Lamprinos, 1998; Katsikis, 2001; Klonari, 2002; Klonari \& Koutsopoulos, 2005). Taking into consideration the fact that many researchers admit that children's learning is improving as their interest increases (Shaughnessy, Haladyna, 1985; Sack, Petersen, 1998; Jacobson, 2000). As well as that the development of positive attitudes towards a subject early in students' lives often affect what a person chooses to learn more about it later in his life (Carswell, 1970, Sack, Petersen, 1998, Whitlock, 2006), then it is certain that further research on the topic will be required, for the purpose of detecting the factors that affect the "misfortune" of geographic education in Greece, and taking appropriate steps to address these effectively.

Previous researches concerning the status of Geography in Greek educational system show that Geography, from its inclusion in school curricula until this day, has been classified among the minor subjects, the ones called "secondary" by teachers and students. It has been treated as a "supplement" of the hourly schedule, and despite the efforts made during the last few years for the renewal thereof, it is quite far from being labeled as a significant subject in Greek educational system. Geography position in the Greek educational system is continuously degrading and the future seems to be very cloudy and uncertain. Such a view is supported, in particular by reducing its prestige among others science subjects, which leads to the continuous reduction of weekly hours of geography teaching in compulsory education and the replacement of subject content with other science ones. (Rentzos, 1984; Katsikis, 2001; Klonari, 2004; Rellou \& Lamprinos, 2004; Klonari, 2012).

Also, other researchers have stressed that despite the fact that in the past remarkable efforts had been made for the improvement and modernization of geographical knowledge at schools (Katsiapi, Klonari, 2000; Pramas., Koumaras., 2004), through new geography curricula (Hellenic Government Gazette: 241/1996, 335/2000, 1375/2001, 364/2003), new geography textbooks, creation of new educational material (Anagnostopoulos et al., 2001) educational software and finally organization of short teacher training seminars, still there has been little, if any, improvement of the image and status of the subject, and teaching methods implemented in the classroom practices (Klonari, Karanikas, 2004).

A previous research conducted by Klonari (2004), in which the opinions and attitudes of Primary and Secondary Education teachers with regard to the subject of Geography at the Greek school are investigated, showed the following results: a) teachers accept that Geography is a useful subject, and it must be taught at school and b) primary education teachers by $48 \%$ and secondary education by an even greater rate $(65 \%)$ stated that they do not like the subject, they do not want to teach it, and they would prefer to teach other subjects. As an excuse for their negative attitude towards the subject both Primary and Secondary Education teachers reported: a) the inadequacy of knowledge, as they were not taught at all or were inadequately taught this subject at the University or the Academies, b) the bad experience from being taught such subject as students (learning by heart etc.), c) the lack of 
suitable educational material so that the lesson will become attractive, and d) lack of time for the preparation of the lesson in accordance with the requirements of the "new Curricula" (Klonari, 2004). But, a more recent research (Paraskevas, et al. 2010) showed that most of the teachers pursued new teaching approaches that would support the educational needs in teaching geography.

Recently, innovative approaches to teaching geography adopted in the new geography curriculum, and new digital educational material implemented in student activities, as part of the new school: the school of the 21 st century (Klonari, et al., 2014).

In this framework, the purpose of our research is to investigate whether the image of the subject of geography has improved both as regards teachers and students, and whether and how the teacher's attitude influences the attitude and the students' performance in the subject of geography.

\section{Method}

\subsection{Research Sample}

The research used 600 6th-grade students from all over Greece. In total, the 600 students were 11-13 years old (Mean Value=11.75 Standard Deviation=0.46), and came from 22 different schools, divided into 33 different classes. Out of these classes, 18 (54.6\%) belonged to pilot schools, which were required to implement the new Geography Curriculum (use of technologies and innovative approaches, without a specific textbook), while 15 (45.4\%) followed the older Cross-thematic Geography Curriculum and the approved school geography textbooks. Out of the total of the participating students, 301 were boys $(50.2 \%)$ and $299(49.8 \%)$ were girls. The 33 teachers for each class also participated in the research. Out of them 10 were men $(30.3 \%)$ and 23 were women $(69.7 \%)$, aged from 27 to 57 (M.V=40.8 S.D $=9.31)$. Only 7 teachers $(21.2 \%)$ were taught the subject of geography at university, and 13 teachers $(39.4 \%)$ had participated in the inservice teachers' training seminars, workshops, regarding the effective implementation of the new Geography Curriculum in their classes.

\subsection{Research Tools}

We used the following research tools in our research: a) a two-part questionnaire: its 1st part involved demographic details of the participants, and its 2 nd part contained questions relating to exploring the attitudes of teachers and students towards the subject of geography; b) an assessment test with geography activities relating to the students' spatial skills, in accordance with the model of Gersmehl \& Gersmehl (2007), for the purpose of measuring the students' performance in the specific course, in combination with the grade they had in the term, and the score they received in the last geography assessment test they had taken in the classroom. 


\section{Results}

To begin with, the students were asked to evaluate by order of significance six core subjects of their grade (Language, Mathematics, Physics, Geography, History, Religion), where 1 means the subject they prefer the most and 6 means the subject they prefer the least. Table 1 presents the frequencies of preferences for all six subjects. It appears that science subjects (Mathematics, Physics) collect the most first preferences (37.9\% and 23.6\% respectively), while Geography (5.7\%) surpasses only Religion (1.8\%) in first preferences. Only $26.7 \%$ of the sample places Geography among their first preferences, under only Mathematics $(60.5 \%)$ and Physics (57\%), while $46.5 \%$ of the sample places Geography higher in preference only than History (36\%) and Religion (19.8\%). The students' preferences were checked by the Kendall's W criterion, in order for the degree of consistency between them to be determined. The criterion value was $\mathrm{W}=0.22[\chi 2(5)=642,025]$, which is statistically significant, as it is higher than the crucial value for $0.1 \%$. Thus, the null hypothesis (H0) that the students' preferences in subjects do not differ between one another is rejected in favor of the alternative, with $0.1 \%$ error probability. There is systematic differential preference on the part of the students, as regards their preference in subjects (Table 1).

Table 1. Preferences of Sample Students in Six Subjects of Their Grade

\begin{tabular}{|c|c|c|c|c|c|c|c|c|c|c|c|c|}
\hline \multirow{3}{*}{ Subjects } & \multicolumn{12}{|c|}{ Students' Preferences } \\
\hline & \multicolumn{2}{|l|}{$1 \mathrm{st}$} & \multicolumn{2}{|l|}{ 2nd } & \multicolumn{2}{|l|}{$3 \mathrm{rd}$} & \multicolumn{2}{|l|}{ 4th } & \multicolumn{2}{|l|}{5 th } & \multicolumn{2}{|l|}{ 6th } \\
\hline & $f(\%)$ & $c r f$ & $f(\%)$ & $c r f$ & $f(\%)$ & $c r f$ & $f(\%)$ & $c r f$ & $f(\%)$ & $c r f$ & $f(\%)$ & $c r f$ \\
\hline Language & $108(18.1)$ & 18.1 & $102(17.1)$ & 35.2 & $131(21.9)$ & 57.1 & $120(20.1)$ & 77.2 & $76(12.7)$ & 89.9 & $60(10.1)$ & 100 \\
\hline Mathematics & $226(37.9)$ & 37.9 & $122(20.4)$ & 58.3 & $86(14.4)$ & 72.7 & $54(9.0)$ & 81.7 & $49(8.2)$ & 89.9 & $60(10.1)$ & 100 \\
\hline Physics & $141(23.6)$ & 23.6 & $200(33.5)$ & 57.1 & $131(21.9)$ & 79.1 & $68(11.4)$ & 90.5 & $40(6.7)$ & 97.2 & $17(2.8)$ & 100 \\
\hline Geography & $34(5.7)$ & 5.7 & $76(12.7)$ & 18.4 & $121(20.3)$ & 38.7 & $145(24.3)$ & 63.0 & $159(26.6)$ & 89.6 & $62(10.4)$ & 100 \\
\hline History & $76(12.7)$ & 12.7 & $64(10.7)$ & 23.5 & $74(12.4)$ & 35.8 & $94(15.7)$ & 51.6 & $92(15.4)$ & 67.0 & $197(33.0)$ & 100 \\
\hline Religious Studies & $11(1.8)$ & 1.8 & $35(5.9)$ & 7.7 & $60(10.1)$ & 17.8 & $115(19.3)$ & 37.0 & $172(28.8)$ & 65.8 & $204(34.2)$ & 100 \\
\hline
\end{tabular}

Moreover, preferences towards Geography were grouped into two or three categories of attitudes (1st \& 2nd=Very Good, 3rd \& 4th=Medium, 5th \& 6th=Poor), as displayed in Table 3. Only $1 / 6$ of the total sample of students $(18.6 \%)$ stated that they have a very good attitude towards the subject. By contrast, 5/6 appear to have a poor or medium attitude (82.4\%) (Table 2 ). As regards the teachers, there was not even one who exhibited a very good attitude towards the subject; on the contrary, 13 teachers $(43.3 \%)$ reported a poor attitude, and 17 teachers $(56.7)$ reported a medium attitude. 


\section{Macrothink}

Table 2. Attitude of the 600 Students Towards the Subject of Geography

\begin{tabular}{llll}
\hline & $\begin{array}{l}\text { Poor } \\
f(\%)\end{array}$ & $\begin{array}{l}\text { Medium } \\
f(\%)\end{array}$ & $\begin{array}{l}\text { Very good } \\
f(\%)\end{array}$ \\
\cline { 2 - 4 } Attitude towards Geography & $220(36.9)$ & $266(44.6)$ & $111(18.6)$ \\
\hline
\end{tabular}

The teachers selected Mathematics (43.8\%) and Language (37.5\%) as the subjects they best prefer. Also, no one listed Geography among their first two choices, and no one listed it as their last choice. Thus, all of the choices concerned the 3rd, 4th, and 5th position. By contrast, the subject of Religion collected few preferences, since, as it is indicated in Table 3, 75\% of the teachers selected it as their last choice. The criterion value was $W=0.40\left[\chi^{2}(5)=63.25\right]$, which is statistically significant, as it is higher than the crucial value for $0.1 \%$. Thus, the null hypothesis $(\mathrm{H} 0)$ that the teachers' preferences in subjects do not differ between one another is rejected in favor of the alternative, with $0.1 \%$ error probability. There is systematic differential preference on the part of the teachers, as regards their preference in subjects.

Table 3. Preferences of Sample Teachers in Six Subjects of Their Class

\begin{tabular}{|c|c|c|c|c|c|c|c|c|c|c|c|c|}
\hline \multirow{3}{*}{ Subjects } & \multicolumn{12}{|c|}{ Students' Preferences } \\
\hline & \multicolumn{2}{|l|}{1 st } & \multicolumn{2}{|l|}{ 2nd } & \multicolumn{2}{|l|}{$3 \mathrm{rd}$} & \multicolumn{2}{|l|}{4 th } & \multicolumn{2}{|l|}{5 th } & \multicolumn{2}{|l|}{6 th } \\
\hline & $f(\%)$ & $c r f$ & $f(\%)$ & $c r f$ & $f(\%)$ & $c r f$ & $f(\%)$ & $c r f$ & $f(\%)$ & $c r f$ & $f(\%)$ & $c r f$ \\
\hline Mathematics & $14(43.8)$ & 43.8 & $7(21.9)$ & 65.6 & $5(15.6)$ & 81.3 & $1(3.1)$ & 84.4 & $3(9.4)$ & 93.8 & $2(6.3)$ & 100 \\
\hline Physics & $2(6.3)$ & 6.3 & $10(31.3)$ & 37.5 & $4(12.5)$ & 50.0 & $10(31.3)$ & 81.3 & $5(15.6)$ & 96.9 & $1(3.1)$ & 100 \\
\hline History & $3(9.4)$ & 9.4 & $9(28.1)$ & 37.5 & $8(25.0)$ & 62.5 & $3(9.4)$ & 71.9 & $6(18.8)$ & 90.6 & $3(9.4)$ & 100 \\
\hline Religious Studies & $1(3.1)$ & 3.1 & - & - & $1(3.1)$ & 6.3 & $4(12.5)$ & 18.8 & $1(3.1)$ & 21.9 & $25(75.8)$ & 100 \\
\hline
\end{tabular}

Table 4. Distribution of Frequencies of Students' Answers to the Question "What you do not like in Geography"

\begin{tabular}{lllll}
\hline & \multicolumn{3}{l}{$1^{\text {st }}$ option } & \multicolumn{3}{l}{ option } \\
\cline { 2 - 5 } & $f$ & $\%$ & $f$ & $\%$ \\
\hline Vast, condensed subject content & 161 & 26.8 & 2 & 0.3 \\
Learning by heart & 93 & 15.5 & 46 & 7.7 \\
Too much homework & 73 & 12.2 & 57 & 9.5 \\
Poor-written books & 31 & 5.2 & 23 & 3.8 \\
Boring teaching & 26 & 4.3 & 37 & 6.2 \\
Non-use in classroom educational & 20 & 3.3 & 42 & 7.0 \\
material & 19 & 3.2 & 10 & 1.7 \\
All of the above & 177 & 29.5 & 383 & 63.9 \\
Nothing & 600 & 100 & 600 & 100 \\
\hline \multicolumn{2}{c}{ Total } & &
\end{tabular}


Students were also asked to report what they dislike about geography. Table 4 presents their answers to the question "what they dislike most in Geography". Four hundred twenty three students (71.5\%) gave some answer, while 177 (29.5\%) reported "Nothing". As a first option most of them mentioned vast, condensed subject content, learning by heart, and too much homework required by the subject. As a second option students mentioned too much homework, learning by heart, and absence of use proper educational material in teaching and learning activities. About $64 \%$ chose not to give a second answer.

Moreover, most of the teachers reported that they were not taught Geography at University, or that they had not received further training in Geography. Specifically, 26 (78.8\%) teachers were not taught Geography in their university studies, while $20(60.6 \%)$ teachers had not received further training. However, many teachers stated that they believe that they teach the subject with adequate to very high proficiency. Three teachers stated that they feel extremely proficient to teach the subject, 12 stated that they feel very proficient, while 16 teachers reported that they feel adequately proficient. Thus, practically only two teachers stated their inadequacy to teach the specific material.

They mainly mentioned that they dislike the geography content $(51.5 \%)$, and the inadequacy of the educational material, and classroom infrastructure (42.4\%). Fewer of them face difficulties with the geography textbook (39.4\%) and learning by heart (33.3\%). All of them stated that they use the textbook (but for one) and the maps as teaching material. Computers are used by 23 teachers $(69.7 \%)$, while nine teachers $(27.3 \%)$ use a specific software, and 12 of them $(36.4 \%)$ use photocopies. Also, nine teachers $(27.3 \%)$ used the lesson portfolio, prepared by themselves. Finally, two teachers reported using an interactive environment (interactive whiteboard) for the activities, while another one described teaching in his classroom through the use of sources and small projects.

The lesson is primarily taught in groups in the classroom (23 teachers), while nine teachers mentioned that they apply traditional teaching methods (teacher-centred). A teacher mentioned that he alternates teaching modes (individual/group teaching).

As regards the practical usefulness of the subject of Geography, seven teachers believe that it has some usefulness $(21.1 \%)$, sixteen $(48.5 \%)$ teachers report high usefulness, while ten $(30.3 \%)$ teachers believe that Geography is extremely useful for the person's life later on.

We also investigated whether teacher's training affects the attitude and the performance of students in the subject of geography. The existence of additional training of teachers in Geography did not seem to influence their attitude towards this subject $[\Phi(1)=, 25 \mathrm{p}=, 18]$. Moreover, having been taught the subject at the University again did not appear to influence their attitude towards this subject $[\Phi(1)=, 22 \mathrm{p}=, 21]$. Likewise, the students' attitude towards Geography did not seem to correlate either with whether teachers had been taught this subject at University $\left.\chi^{2}(2)=5.48 \mathrm{p}=, 07\right]$, or whether they had received additional training $\left[\chi^{2}(2)=, 24\right.$ $\mathrm{p}=, 89]$.

Then, we checked the relationship between teachers' being taught Geography and being trained in it, on the one hand, and students' performance, on the other hand. With regard to 
being taught Geography at University, it did not seem to differentiate the students' performance in the Geography test (Mann-WhitneyU $=29.620,5 \mathrm{p}=, 42$ ), or in the examination (Mann-Whitney $U=29.718 p=, 38$ ), or in the score for the term (Mann-WhitneyU $=30.828$ $\mathrm{p}=, 10$ ). By contrast, significant variation appeared in students' performance in the Geography test they took during this research (Mann-WhitneyU $=38.499 \mathrm{p}<, 05$ ). The students whose teachers had not received prior training in the subject of Geography achieved a better score $($ T.T. $=311.45)$ than the ones whose teachers stated that they had received training $($ T.T. $=282.89)$. No differences were observed in scores for the term (Mann-WhitneyU $=45.625,5 \quad \mathrm{p}=, 11$ ), or in the latest Geography test (Mann-WhitneyU=43.737,5 p=,56).

Another issue that taken into consideration in our research was the teachers' prior working experience. The teachers' years of service were checked as a differentiating factor as regards the attitude of teachers and students towards the subject. The check conducted by the criterion $\chi 2$ did not reveal any statistically significant result. In particular, no statistically significant difference was detected $[\chi 2(4)=2,90, p=, 58]$ as to the attitude of teachers towards the subject depending on the years of service they had (6-10, 11-15, 16-20, 21-25, >26). Also, the years of prior working experience of the teachers did not seem to affect the attitude of students towards Geography $[\chi 2(8)=8,86, \mathrm{p}=, 36]$.

Then, it was investigated whether students' performance varies as to their overall performance, the Geography test for the term, and the Geography assessment test (related to spatial skills) and the Final Examination test during this research, depending on the years of prior working experience of their teachers (Table 5). With regard to the Geography test, the students whose teachers had small prior working experience (6-0 years) achieved a lower performance, compared with the other students. In particular, they differed from students with teachers with 11-15 years of prior working experience $(\Delta \check{\mathrm{R}}=-64.05 \mathrm{p}<, 05)$, from students with teachers with 21-25 years of prior working experience $(\Delta \breve{R}=-155.51 \mathrm{p}<, 001)$, and from students with teachers with more than 26 years of prior working experience $(\Delta \breve{\mathrm{R}}=-80.61$ $\mathrm{p}<, 05)$. Moreover, students whose teachers had 21-25 years of prior working experience achieved higher performance, compared with the students whose teachers had fewer years of prior working experience, i.e. $11-15(\Delta \breve{\mathrm{R}}=-91.46 \mathrm{p}<, 001)$ and $16-20(\Delta \breve{\mathrm{R}}=-125.53 \mathrm{p}<, 001)$. As regards their score in the Geography assessment test (related to spatial skills), students whose teachers had little prior working experience (6-0 years) had lower performance, compared with students of teachers who reported 11-15 years of prior working experience $(\Delta \breve{\mathrm{R}}=-59.90$ $\mathrm{p}<, 05)$, and students of teachers with more than 26 years of prior working experience $(\Delta \breve{\mathrm{R}}=-80.82 \mathrm{p}<, 05)$. Finally, as regards their score for the term, students whose teachers had little prior working experience (6-0 years) had lower performance, compared with students of teachers who reported 11-15 years of prior working experience $(\Delta \breve{\mathrm{R}}=-52.51 \mathrm{p}<, 05)$, and students of teachers with more than 26 years of prior working experience $(\Delta \breve{\mathrm{R}}=-67.74 \mathrm{p}<, 05)$. 
Table 5. Check by the Kruskal-Wallis Criterion of the Comparison of the Regular Values of the Students' Performance as to the Years of Prior Working Experience of Their Teachers

\begin{tabular}{lcccccc}
\hline & \multicolumn{9}{c}{ Prior working experience of teachers } & \\
\cline { 2 - 5 } School performance & $\begin{array}{c}\text { 6-10 years } \\
(N=194)\end{array}$ & $\begin{array}{c}11-15 \text { years } \\
(N=132)\end{array}$ & $\begin{array}{c}16-20 \text { years } \\
(N=113)\end{array}$ & $\begin{array}{c}21-25 \text { years } \\
(N=103)\end{array}$ & $\begin{array}{c}>26 \text { years } \\
(N=58)\end{array}$ & $\begin{array}{c}\text { Kruskal-Wa } \\
\text { llis } H \\
(\text { B.E.4 })\end{array}$ \\
\hline $\begin{array}{l}\text { Geography Test } \\
\text { (related to spatial skills) }\end{array}$ & $246.28_{\mathrm{a}, \mathrm{b}, \mathrm{c}}$ & $310.32_{\mathrm{a}, \mathrm{e}}$ & $276.26_{\mathrm{d}}$ & $401.78_{\mathrm{b}, \mathrm{d}, \mathrm{e}}$ & $326.89_{\mathrm{c}}$ & $58.14^{* * *}$ \\
Score for the term & $271.22_{\mathrm{a}, \mathrm{b}}$ & $323.73_{\mathrm{a}}$ & 295.92 & 309.24 & $338.96_{\mathrm{b}}$ & $13.06^{*}$ \\
Final examination score & $270.34_{\mathrm{a}, \mathrm{b}}$ & $330.24_{\mathrm{a}}$ & 303.74 & 287.10 & $351.15_{\mathrm{b}}$ & $15.96^{* *}$ \\
\hline
\end{tabular}

$* \mathbf{p}<, 05 . * * \mathbf{p}<, 01 . * * * \mathbf{p}<, 001$

Note: The average scores with the same indices show differences in pairs $(p<0.05)$.

Finally, it was checked whether there is any variation in terms of the separation of the curriculum into pilot and traditional one, as regards the attitude of 6th-grade students towards Geography. No statistically significant difference was traced [Mann-Whitneyz=-,58, $\mathrm{p}=, 56$ ] in terms of the manner in which students understand their relationship with the subject.

\section{Conclusions-Discussion}

According to the findings of this research, it was observed that the attitude of students and teachers towards geography has not changed since it was researched for the last time in Primary Education (Katsikis, 2001; Klonari, 2002; 2004; Klonari \& Koutsopoulos, 2005). With the application of the new curricula of studies and the use of New Technologies and the digital school, one would expect that an evident improvement would be made as regards the attitude of both students and teachers towards the subject. Nevertheless, the same negative attitude towards geography is still observed, and it continues being a minor subject. Only $1 / 6$ of the total sample reported a very good attitude towards the subject, while 5/6 (82.4\%) showed a medium or poor attitude.

Moreover, it is interesting that although the teachers stated that they consider geography to be very or somewhat useful for the person's future life, yet not even one teacher demonstrated a very good attitude towards the subject. By contrast, $43.3 \%$ reported poor attitude, and $56.7 \%$, i.e. more than half of them, reported medium attitude. It should also be noted that in a previous research (Klonari et al., 2014), most of the teachers stated that they were particularly satisfied with the new curriculum and the teacher's book. Thus, this attitude may be attributed either to the erroneous application of the new curriculum, or to inadequate teaching (Klonari et al., 2011).

In older studies, teachers attributed such negative attitude to the lack of educational material (Klonari, 2004). However, today, with the creation of new 2D and 3D maps, air photographs, rich educational material (learning objects) and educational software on Photodentro (Greek 
National Aggregator of the Digital School), accessible to everyone, and from everywhere (easy access of schools to the Internet), geographic education should have escaped the traditional teaching models and should be relying on active-discovery methods, based on holistic, active, experiential involvement of students, which would make the course of geography particularly appealing, interesting and exciting to children, it seems that this is not among the teachers' intentions. This is probably due to their unwillingness to further prepare the lessons, or to the pressure of the content that must be taught or because the use of technology is not so active and based on experiental involvement of students but traditional (for example only presentations with power point).

It was also observed in this research that teachers' training did not seem to affect the attitude of either the teachers themselves or their students. It was quite striking that in the Geography test to which the sample students were assessed, the students whose teachers had not received training achieved better performance. This may be due to the fact that the preexisting personal experiences of teachers from their student years are very powerful, and affect teaching to a large extent (Klonari et al., 2011; Molin et al., 2015), and short-term training cannot have particular results. Moreover, the fact that most of the teachers consider themselves efficient to teach the subject of geography doesn't agree with the students' performance in geography tests. This fake image that have for themselves probably doesn't let them improve themselves through educational training.

It is also worth to be noted that although most of the teachers (except for two) stated that they were extremely or adequately proficient to teach the subject of geography, still they face difficulties with the textbook (39.4\%). Therefore, we observe that teachers do not have a clear and realistic image of their teaching.

Finally, it was observed that the teachers' experience plays a significant role in their teaching, and in the long run, in the students' performance in the subject of geography. Students with experienced teachers showed better performance in the geography test, compared with students whose teachers had fewer years of prior working experience.

\section{References}

Adeyemi, B. (2010). Teacher Related Factors as Correlates of Pupils Achievement in Social Studies in South West Nigeria. Electronic journal of Research in Educational psychology, $8(1), 313-332$.

Alderman, M. K. (2008). Motivation for Achievement: Possibilities for Teaching and Learning. New York, NY: Routledge

Ames, C., \& Archer, J. (1988). Achievement goals in the classroom: Students' learning strategies and motivation processes. Journal of Educational Psychology, 80(3), 260-267

Anagnostopoulos, E., Klonari, Aik., Pigaki, M., \& Tsounakos, Th. (2001). Educational material for teaching Geography. Athens (in Greek). 
Brophy, J., \& Good, T. (1986). Teacher behavior and student achievement. In M. Wittrock (Ed.), Handbook of research of teaching (3rd Ed.). New York: McMillan.p.328-275.

Burden, P.R., \& Byrd, D.M. (1994). Methods effective teaching. Boston: Allyn and Bacon.

Carswell, R. (1970). Evaluation of affective learning in geographical education. Evaluation in geographic education. Belmont, California: Fearon Publishers, 109-27.

Chalkia, K. (1999). Attitudes of Greek Teachers in Primary and Secondary Education to the course of Physics. Modern Education, 106, 47-56. (in Greek)

Coffin, S.G. (1994). Curriculum models and early childhood education. Appraising the relationship. New York: Merrill.

Flouris, G. (2000). Curriculum for a New season in Education (7th Ed.). Athens: Gregory.(in Greek)

Gersmehl, F., \& Gersmehl, A. (2007). Spatial thinking by young children: Neurologic evidence for early development and "educability". Journal of Geography, 106, 181-191. https://doi.org/10.1080/00221340701809108

Harris, A. (1998). Effective teaching: A review of the literature. School Leadership \& Management, 18(2), 169-183. https://doi.org/10.1080/13632439869628

Heck, R.H. (2009). Teacher Effectiveness and Student Achievement. Investigating a Multilevel Cross-Classified Model. Journal of Education Administration, 7(22), 227-249. https://doi.org/10.1108/09578230910941066

Jacobson, L. (2000). Valuing diversity-student-teacher relationships that enhance achievement. Community College Review, 28, 49-66. https://doi.org/10.1177/009155210002800104

Joyce, B., \& Weil, M. (1996). Models of teaching (4th ed.) Englewood Cliffs, NJ: Prentice-Hall.

Katsiapi, N., \& Klonari, Aik. (2000). 7th Grade Students Evaluate the Geography Textbook. 2nd Pan-Hellenic Conference "Science Teaching and Implementation of New Technologies in Education". Nicosia, Cyprus, 3-5 May 2000. (in Greek)

Katsikis, A. (2001). Geography and geographic education: Crisis reasoning- An innovative intervention proposal. Geographies, 2, 15-29.(in Greek)

Klonari A., \& Koutsopoulos, K. (2005). Primary and secondary educators' attitudes on school geography. In K. Donert \& P. Charzynski (Ed.), Changing horizons in geography education, 151-155. Torun, Poland: Herodot Network

Klonari Aik., \& Karanikas, C. (2004). Comparison of the Geography lesson topics of June examinations of 7th Grade in 1999 and 2003. Proceedings 10th Panhellenic Conference of Science, E.E.F., Volume A, "Education and Teaching of Science". Loutraki January 29-1 February2004, 159-162. (In Greek).

Klonari Aik.. (2002). The place of Geography in Primary Greek Education. Proceedings of the 
6th Pan-Hellenic Geographical Conference, Thessaloniki, 3-6 October 2002, I, 529-540 (in Greek)

Klonari, A. I. (2012). Primary school pupils' ability to use aerial photographs and maps in the subject of geography. European Journal of Geography, 3(2), 42-53.

Klonari, A., Dalaka, A., \& Petanidou, Th. (2011). How evident is the apparent? Students and teachers perception of the terraced landscape. International Research in Geographical and Environmental Education, 20(1), 5-20. https://doi.org/10.1080/10382046.2011.540100

Klonari, A., Mandrikas, A., Melista, A., \& Tzoura, M. (2014). One year pilot implementation of the new Greek geography curriculum in primary education. European Journal of Geography, 5(1), 81-97.

Lamprinos, N. (1998). Geographic Education: A Challenge for the Greek reality of the 21 st century. Modern Education, 104, 40-46. (in Greek)

Luciano, J. (2014). The Influence of Curriculum Quality on Student Achievement on the New Jersey Assessment of Skills and Knowledge (NJ ASK) Language Arts and Mathematics for Fifth-Grade Students in the Lowest Socioeconomic School Districts. Seton Hall University Dissertations and Theses (ETDs). Paper 2017. http://scholarship.shu.edu/dissertations

Matsagouras, H. (2000). Group-cooperation Teaching and Learning. Athens: Grigoris.(in Greek)

Moler, M. C. (2008). The Relationship between the Curriculum, Instruction, and Assessment Provided by Wyoming High School Mathematics Teachers and the Performance of Wyoming 11th Grade Students on the Adequate Yearly Progress of Wyoming Schools. Public Access Theses and Dissertations from the College of Education and Human Sciences. Paper 24. http://digitalcommons.unl.edu/cehsdiss/24

Molin, L., Grubbstrom, A., Bladh, G., Westermark, A., Ojanne, K., Gottfridsson, H., \& Karlsson, S. (2015). Do personal experiences have an impact on teaching and didactic choices in geography?. European Journal of Geography, 6(4), 6-20.

Paraskevas, A., Lambrinos, N., \& Psillos, D. (2010). A study of a blended didactic approach to teacher professional development in Geography. European Journal of Geography, 1, $15-28$.

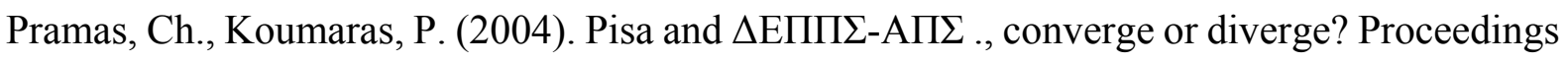
of the 2nd Conference EDFE 'Teaching Science and Technology, the challenges of the 21st century", Kalamata 18-20 March 2004.(In Greek).

Prassas. (2013). School performance, school failure and success. Presentation at the 1st High School of Zakynthos entitled "From primary to high school, from childhood to adolescence". (in Greek). 
Rellou, M., \& Lamprinos, N. (2004). The stagnation of geographic education in primary and lower secondary schools. Proceedings of the 7th Pan- Hellenic Geographical Conference, 547-554. Mytilene, Lesvos island. (In Greek).

Rentzos, G. (1984). Geographical Education. Athens: Epikerotita.

Rose, A. (1989). What do effective teachers do? .The Clearing House, 63(4), 181-183.

Rosenshine, B. (1983). Teaching functions in instructional programs. Elementary School Journal, 83(4), 335-351.

Sack, D., \& Petersen, J. F. (1998). Children's Attitudes toward Geography: A Texas case study. Journal of Geography, 97(3), 123-131. https://doi.org/10.1080/00221349808978836

Schneider, F.W., Coutts, L.M., \& Gruman, J.A. (2012). Applied social psychology: Understanding and addressing social and practical problems $\left(2^{\text {nd }}\right.$ ed.). Thousand Oaks, California: Sage Publications, Inc.

Shaughnessy, J. M., \& Halabyna, T. M. (1985). Research on student attitude toward the social studies. Social Education, 49, 692-695.

Soric, T. M. (2011). The impact of teacher attitudes on academic achievement in disadvantaged schools Theses and Dissertations. Paper 727. Open access by The University of Toledo Digital

Repository. http://utdr.utoledo.edu/cgi/viewcontent.cgi?article=1748\&context=theses-dissertations

Stronge, H. J. (2007). Qualities of Effective Teachers (2nd Ed.). ASCD.

Ulug, M., Ozden, M. S., \& Eryilmaz, A. (2011). The effects of teachers' attitudes on students' personality and performance. Procedia-Social and Behavioral Sciences, 30, 738-742. https://doi.org/10.1016/j.sbspro.2011.10.144

Whitlock, J.L. (2006). Youth perception of life in school Contextual correlates of school connectedness in adolescence. Applied Developmental Science, 10(1), 13-29. https://doi.org/10.1207/s1532480xads1001_2

Wright, S.P., Horn, S.P., \& Sanders, W.C. (1997). Teacher and Classroom Context Effects on Student Achievement: Implications for Teacher Evaluation. Journal of Personnel Evaluation in education, 11, 57-67.

Zhuang, J. (2010). The Changing Role of Teachers in the Development of Learner Autonomy-Based on a Survey of "English Dorm Activity". Journal of Language Teaching and Research, 1(5), 591-595. https://doi.org/10.4304/j1tr.1.5.591-595

\section{Copyright Disclaimer}

Copyright for this article is retained by the author(s), with first publication rights granted to the journal.

This is an open-access article distributed under the terms and conditions of the Creative Commons Attribution license (http://creativecommons.org/licenses/by/3.0/). 